\title{
STUDY ON COMBUSTION CHARACTERISTICS OF COAL-BIOMASS FOR CO-FIRING SYSTEM AS A FEEDSTOCK OF COAL GASIFICATION PROCESS
}

\author{
STUDI SIFAT PEMBAKARAN BATUBARA-BIOMASSA UNTUK \\ SISTEM PEMBAKARAN BERSAMA SEBAGAI UMPAN PROSES \\ GASIFIKASI BATUBARA
}

\author{
DATIN F. UMAR, GANDHI K. HUDAYA and FAHMI SULISTYOHADI \\ $R$ \& D Centre for Mineral and Coal Technology \\ Jalan Jenderal Sudirman 623 Bandung 40211 \\ Ph. (+6222) 6030483, Fax. (+6222) 6003373 \\ e-mail: datinf@tekmira.esdm.go.id
}

\begin{abstract}
Biomass co-firing is recognised as a crucial technology to aid in the use of fossil fuels, particularly due to its relative ease of implementation. Many studies of the combustion processes associated with cofiring have been conducted elsewhere. This paper discusses the combustion characteristics of coal and torrefied biomasses. Combustion profiles can be used to study certain combustion properties of fuels and fuel blends. The biomass fuels utilized in this study include twig, trunk and weed as the wastes from tea plantation. The results of this work provide data concerning the combustion processes of co-firing determined by simultaneous thermal analysis (STA) methods. Simultaneous thermogravimetric \& differential scanning calorimetry/differential thermal analysis (STA, TGADSC/DTA) measures both the heat flow (DSC) and the weight changes (TG) in a material as a function of temperature or time in a controlled atmosphere. The results indicate that the mixture of coal and torrefied trunk in the weight ratio of coal-trunk of 25:75 shows the best combustion performance compared to other compositions of coal - torrefied biomass.
\end{abstract}

Keywords: coal, biomass, co-firing, torrefaction, combustion

\begin{abstract}
ABSTRAK
Sistem pembakaran bersama (co-firing) diakui sebagai teknologi yang dapat membantu dalam membatasi penggunaan bahan bakar fosil, terutama karena mudah untuk diimplementasikan. Beberapa studi tentang proses pembakaran terkait dengan pembakaran bersama ini telah banyak dilakukan. Makalah ini membahas karakteristik pembakaran batubara dan biomasa yang telah mengalami proses pengarangan (torrefaction). Profil pembakaran dapat digunakan untuk mempelajari sifat pembakaran bahan bakar dan campuran bahan bakar. Biomassa yang digunakan dalam penelitian ini adalah ranting, batang dan gulma yang diperoleh dari perkebunan teh sebagai limbah. Hasil penelitian adalah data mengenai proses pembakaran bersama yang ditentukan dengan metode simultaneous thermal analisis (STA). Simultaneous thermal analysis, thermogravimetry \& differential scanning calorimetry/differential thermal analysis (STA, TGA-DSC/DTA) mengukur baik aliran panas (DSC) maupun perubahan massa (TG) sebagai fungsi suhu atau waktu dalam suasana terkendali. Hasil penelitian menunjukkan bahwa campuran batubara dan batang yang telah diarangkan dengan perbandingan berat batubara-batang 25:75 menunjukkan sifat pembakaran terbaik dibandingkan dengan komposisi batubara - biomassa lainnya yang diteliti.
\end{abstract}

Kata kunci: batubara, biomasa, pembakaran bersama, pengarangan, pembakaran. 


\section{INTRODUCTION}

The rapid growth of industry and population during the last few decades increased both energy demand and pollution in the world. Electricity is the most convenient form of energy carrier necessitating a large demand in the modern society. In spite of the limited reserve, the fossil fuels are likely to dominate the electricity generating resources at least for the next few decades. However, the largescale use of carbon-based fossil fuels has resulted in utility power generation as one of the major contributors of anthropogenic carbon emission in the environment (Bhattacharya and Datta, 2015).

Among various fossil fuels, coal and natural gas are widely used for electricity generation and are considered as main sources of greenhouse gas (GHG) emissions. Coal alone accounted for $46 \%$ of $\mathrm{CO}_{2}$ emissions in 2013 and its consumption is expected to increase by $33 \%$ in 2035 compared to that in 2009 (IEA, 2011, 2014). However, due to the large reserves, Indonesia relies heavily on coal for electricity generation. Coal accounts for about a third of total power generation in Indonesia and therefore constitutes the second-largest energy source in Indonesia after oil (which accounts for 44 percent). Coal will continue to be the dominant fuel for use in electricity production in order to increase the electrification ratio from $87.5 \%$ in 2015 to $97.2 \%$ by 2019 . To support the project, the Government of Indonesia announced a target to develop $35 \mathrm{GW}$ of new capacity where $60 \%$ of which is a coal-fired power plant (Kementerian Energi dan Sumber Daya Mineral, 2016). As such, the air pollution emissions accompanying the coal combustion will also significantly increase. Among these pollutants are oxides of sulfur (SOx) and nitrogen (NOx), which lead to acid rain and ozone depletion. In addition, greenhouse gas emissions $\left(\mathrm{CO}_{2}, \mathrm{CH}_{4}\right.$, etc.) have become a global concern (Bhuiyan and Naser, 2015).

One way of reducing carbon emission from the power sector is to avail energy conversion techniques with higher efficiency (Cheng et al., 2011). Combined cycle based power generation has the potential of significantly increasing the thermal efficiency of power plants. As coal is the most abundantly available fossil fuel, combined cycle with integrated coal gasification (IGCC) has a great promise as the alternative electricity generation technology of the future (Ahmed et al., 2017).

Another practical and low-cost option of reducing carbon emission is the use of biomass as an energy resource (McllveenWright et al., 2011). Due to their short life cycle, biomass fuels are often considered to be carbon neutral in nature. Madanayake et al. (2017), noted that the major shortcomings of biomasses as a resource were their distributed nature and low energy and mass densities. Mun et al. (2016) showed that the optimal location of the plant with respect to the available biomass sites held a considerable impact on the cost of large scale energy production from biomass. Consumption of biomass as the sole fuel resource for a large power station may not be an attractive alternative either economically or logistically. However, biomass can be used as a supplementary fuel along with the conventional fossil fuel in the plant, either in a co-firing mode or as a re-burning fuel (Duong et al., 2010; Mun et al., 2016). Another characteristic of biomass is its climate neutral behavior. If biomass is grown in a sustainable way, its production and application produce no net amount of $\mathrm{CO}_{2}$ in the atmosphere. The $\mathrm{CO}_{2}$ released by the application of biomass is stored in the biomass resource during photosynthesis and is extracted from the atmosphere which means a climate neutral carbon cycle of $\mathrm{CO}_{2}$ (van der Stelt et al., 2011; Madanayake et al., 2017). Another advantage of co-firing biomass with coal involves the higher volatility of biomass. This has the effect of improving the reactivity and ignition characteristics of the fuel, compared to pure coal (Restrepo and Bazzo, 2016).

However, biomass is classified as a lowgrade fuel which naturally contains undesired properties, such as high moisture content, high ash content and low energy density. Thus, direct utilization of biomass seems to face great barriers overcoming the above drawbacks (Wannapeera and Worasuwannarak, 2012). Torrefaction is one of the thermal treatment techniques, which aims to improve the fuel properties attractively for further utilization such as combustion, gasification and/or co-firing.

Torrefaction, sometimes also referred to as mild-pyrolysis, is a thermochemical process conducted in the temperature range between 200 and $300^{\circ} \mathrm{C}$ under an inert atmosphere and 
low heating rate (Septien et al., 2012; Ma et al., 2016). Torrefaction is currently being considered as a biomass feedstock pretreatment particularly for thermal conversion systems. During torrefaction, various permanent and condensable gases with high oxygen contents, are formed mainly due to hemicellulose degradation. As a consequence, the final solid product, so-called torrefied biomass, will be composed mainly of cellulose and lignin and characterized by increased brittleness, hydrophobicity, microbial degradation resistance, and energy density (Medic et al., 2012).

There are five main stages that have been defined in the total torrefaction process are:

- Initial heating: the biomass is initially heated until the stage of drying of the biomass is reached. In this stage, the temperature is increased, while at the end of this stage moisture starts to evaporate.

- Pre-drying: at $100^{\circ} \mathrm{C}$ the free water is evaporated from the biomass at a constant temperature.

- Post-drying and intermediate heating: the temperature of the biomass is increased to $200^{\circ} \mathrm{C}$. Physically bound water is released, while the resistance against mass and heat transfer is within the biomass particles. During this stage, some mass loss can occur as light fractions can evaporate.

- Torrefaction: during this stage, the actual process occurs. The torrefaction will start when the temperature will reach $200^{\circ} \mathrm{C}$ and end when the process is again cooled down from the specific temperature to 200 ${ }^{\circ} \mathrm{C}$. The torrefaction temperature is defined as the maximum constant temperature. During this period most of the mass loss of the biomass occurs.

- Solids cooling: the torrefied product is further cooled below $200^{\circ} \mathrm{C}$ to the desired final temperature, which is the room temperature.

Thus torrefaction can play a significant role in decreasing transportation and storage costs of biomass in the large quantities needed to sustain biofuels production. In addition, torrefaction may have positive effect on pyrolysis, gasification, and co-firing units operation by lowering power consumption and cost for biomass grinding, eliminating compounds responsible for high acidity of pyrolysis oil, and by increasing the uniformity of biomass feedstocks (Yan et al., 2009).
Indonesia as an agricultural country has huge resources of biomass. Wastes or residues of a tea plantation such as twigs and trunks that have been worn and discarded, likewise weed as undesirable plants in tea plantation and grow wild and regarded as hindering the growth of tea plants are interesting to be developed as biomass resources. The resources of those biomasses are abundant in tea plantation of Gambung, Ciwidey, West Java.

Research on co-firing of coal and biomass of the tea plantation wastes were conducted to study the possibility of the use of the wastes as fuel with the co-firing system as coalbiomass gasification feedstock. The resulted gas can be used directly for tea drying or be connected to a gas engine to produce electricity (small scale power plant) to meet power requirement of the tea plant and surrounding area. The main objective of this work was to investigate the combustion characteristics of blended coal and torrefied biomass of twigs, trunks, and weeds from tea plantation (Figure 1). Understanding of the combustion characteristics aids in design and maintenance of the gasifier. The good design helps to maximize combustion efficiency and assists in reducing carbon particle emissions. Thermal analysis data can be applied not only to the characterization of different fuels (coal and biomass) but also to the evaluation of combustion performance at high temperatures and heating rates.

In this research, the effects of the properties of blended coal-biomass on its thermal and combustion behaviors were studied using simultaneous thermal analysis (STA) methods. Simultaneous thermogravimetric \& differential scanning calorimetry /differential thermal analysis (TGA-DSC/DTA) measures both heat flow (DSC) and weight changes (TG) in a material as a function of temperature or time in a controlled atmosphere. Simultaneous measurements of these two material properties do not only improve productivity but also simplifies interpretation of the results. The characteristic parameters of each sample, including the ignition (Tig), temperature maximum (Tmax), burnout temperatures (Tbo) and the combustion rate (Rmax), were investigated during the process to identify the thermal properties in the thermal evolution profile of blended coal-biomass. 

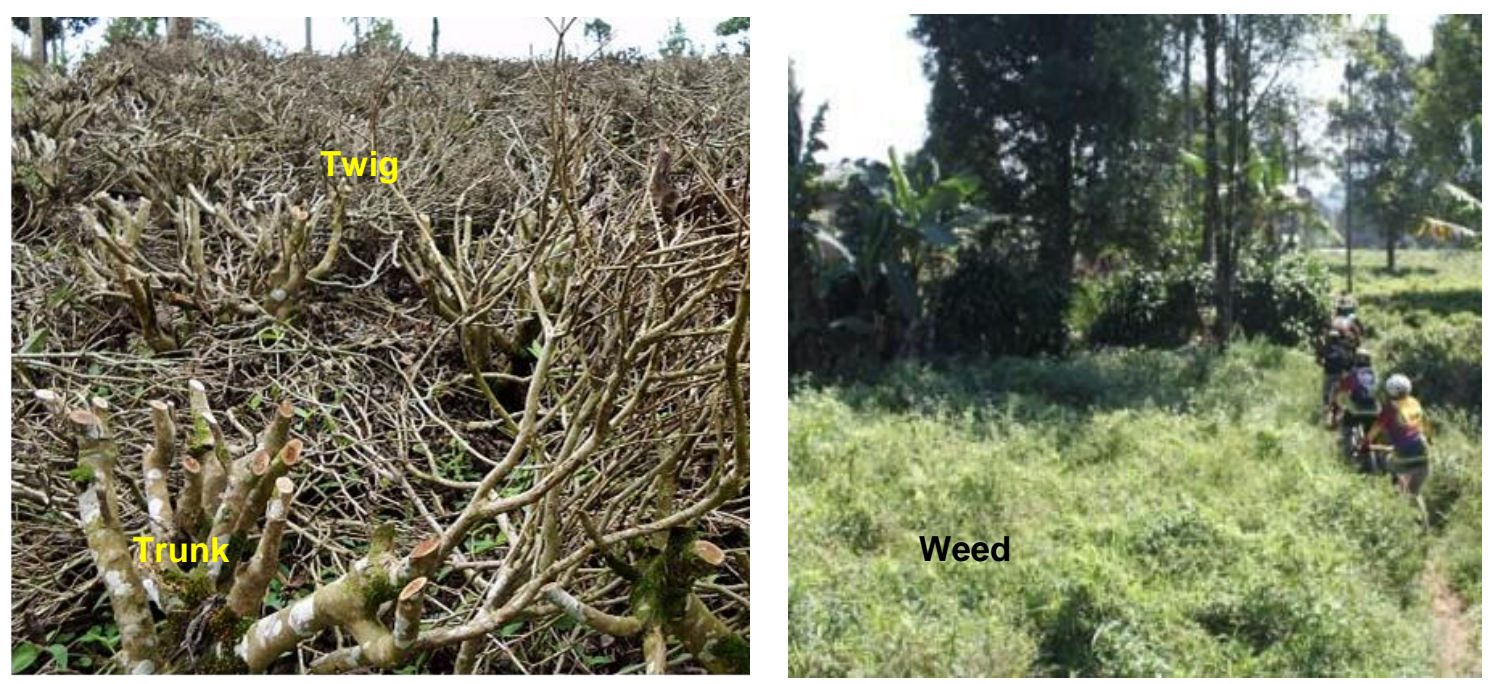

Figure 1. Twig, trunk and weed biomasses

\section{METHODOLOGY}

A coal sample comes from Sorong, Papua and three biomasses of tea plant twigs, tea plant trunks, and tea plant weeds, the wastes/residues of tea plantation were used in this study. The biomasses were torrefied in $1 \mathrm{~L}$ stainless steel container and heated in a reactor at a temperature of $300^{\circ} \mathrm{C}$ for 1 hour under an inert atmosphere and low heating rate to obtain a complete torrefied biomass (Sarvaramini et al., 2014; Neupane et al., 2015). The final torrefied solid product was recovered from the reactor and kept for the next process.

Each sample of the coal and torrefied biomasses was milled and sieved to the desired particle size $( \pm 75 \mu \mathrm{m})$ and was analyzed in order to determine the proximate analysis and calorific value contents. The proximate analysis covers the determination of moisture, volatile matter, and ash and the calculation of fixed carbon according to ASTM D3172-07a Standard Practice for Proximate Analysis of Coal and Coke (ASTM D3172-13, 2013).

Moisture was determined by establishing the loss in weight of the sample when heated under rigidly controlled conditions of temperature, time and atmosphere, sample weight and equipment specifications. One gram of $250-\mu \mathrm{m}$ coal sample was placed in a fused silica capsule with a well-fitting flat aluminum cover. The capsule was then put in a preheated oven (at 104 to $110^{\circ} \mathrm{C}$ ). Close the oven at once and heat for 1 hour. Open the oven, cover the capsule quickly, cool in a desiccator over a desiccant, and weight as soon as the capsules have reached room temperature.

Ash was determined by weighing the residue remaining after burning the coal under rigidly controlled conditions of sample weight, temperature, time, atmosphere and equipment specifications. This test covered the determination of inorganic residue as ash in the coal. Approximately $1 \mathrm{~g}$ of $250-\mu \mathrm{m}$ coal sample was weighed that placed in a porcelain capsule. The coal-containing capsule was then placed in a cold furnace and was heated gradually at such a rate that the temperature reached 450 to $500^{\circ} \mathrm{C}$ for one hour. The coal samples were heated until the final temperature reached 700 to $750^{\circ} \mathrm{C}$ by the end of the second hour. Heating was continued at the final temperature for additional 2 hours (total 4 hours). Then the sample was put in a desiccator in room temperature and weighed.

The volatile matter was determined by establishing the loss in weight resulting from heating a coal under rigidly controlled conditions. The measured weight loss, corrected for moisture as determined in the test as above, establishes the volatile matter content. In this empirical method, the use of platinum crucible with closely fitting cover should be considered as the standard reference method for the volatile matter. One gram of the sample was weighed in a 
weighed platinum crucible. The crucible was closed tight with a cover to prevent he carbon deposit from coal did not burn away from the underside, and inserted directly into a furnace at a maintained temperature of $950 \pm 20^{\circ} \mathrm{C}$. The temperature was then lowered immediately to the $950^{\circ} \mathrm{C}$ zone. After 7-minutes heating, the capsule was allowed to be cooled and weighed as soon as the capsule was cold.

Fixed carbon is the solid combustible residue that remains after a coal particle is heated and the volatile matter is expelled. The fixed carbon content of a coal is determined by subtracting the percentages of moisture, volatile matter, and ash from a sample. All percentages should be on the same moisture reference base.

$F C=100-(M \%+A \%+V M \%)$

The calorific value was determined according to the ASTM D 5865. Gross calorific value or $\mathrm{Qv}$ was the heat produced by complete combustion of coal at constant volume with all water formed condensed to a liquid under specified conditions, while net calorific value or $\mathrm{Qp}$ was the heat produced by combustion of coal at constant pressure of $0.1 \mathrm{Mpa}(1$ atm) with any water formed remaining as vapour. In this research, the adiabatic bomb calorimeter was used to determine the calorific value. Adiabatic calorimeter was a calorimeter that operated in the adiabatic mode and provided with a microprocessor. The initial temperature before initiating the combustion and the final temperature were recorded by the microprocessor.

To study the combustion characteristics of the coal-biomass as a co-firing system, the fine Sorong coal was blended with the fine torrefied biomass (around $75 \mu \mathrm{m}$ ) in a mortar and stirred constantly to form a homogeneous sample. The blending ratio of the coal to biomass based on the mass fraction was 25\%:75\%; 50\%:50\% and 75\%:25\%. Combustion characteristics were conducted using a thermogravimetric analyzer of LINSEIS High-Pressure STA TGA-DTA/DSC as shown in Figure 2. A 12$20 \mathrm{mg}$ sample was placed in an alumina cell at an airflow rate of $25 \mathrm{ml} / \mathrm{min}$ and a heating rate of $10^{\circ} \mathrm{C} / \mathrm{min}$ (Cheng et al., 2011). The maximum experimental temperature was $800{ }^{\circ} \mathrm{C}$. The weight loss of the sample and the rate of the weight loss were recorded continuously under dynamic conditions as functions of time or temperature, and all the experiments were performed at atmospheric pressure, under an inert air atmosphere.

Based on the weight loss curve derived from TG analysis (delta $\mathrm{m} / \mathrm{mg}$ in Figure 3), DSC was calculated. DSC is essentially the slope of the weight loss curve. DSC curves are the burning profiles of the fuels and are essential to clearly observing the onset and behavior of each of the combustion processes. The ignition temperature (Tig) was determined based on the temperature at which the DSC had its peak value and the corresponding slope to the intersection with respect to the TG profile. Tig was taken as the extrapolated onset temperature of the first peak of the DSC curve, which also corresponds to the temperature at which the TG curve departed from the baseline (Figure 3). Ignition temperature corresponds to the Tig of the volatile matter. Tig is an important characteristic of combustion, especially for low-rank coal due to its high intensity of spontaneous combustion (Moon et al., 2013).

Temperature maximum (Tmax) is the temperature at which the maximum rate occurred from the DSC curve. Rmax relates to the maximum combustion rate was defined by taking the first differential at the intersection point of the vertical line at the maximum DSC peak and TG curve:

$$
\operatorname{Rmax}=[\mathrm{d}(\mathrm{TGA}) / \mathrm{dt}]_{\mathrm{T}=\mathrm{Tmax}}
$$

where TGA and $t$ are the weight of the sample in TG curve and time consumed, respectively. While char burnout temperature (Tbo) was defined as the temperature at the minimum DSC peak after the Tmax. Figure 3 shows the determination of combustion parameters derived from the STA TGADTA/DSC analyses. 


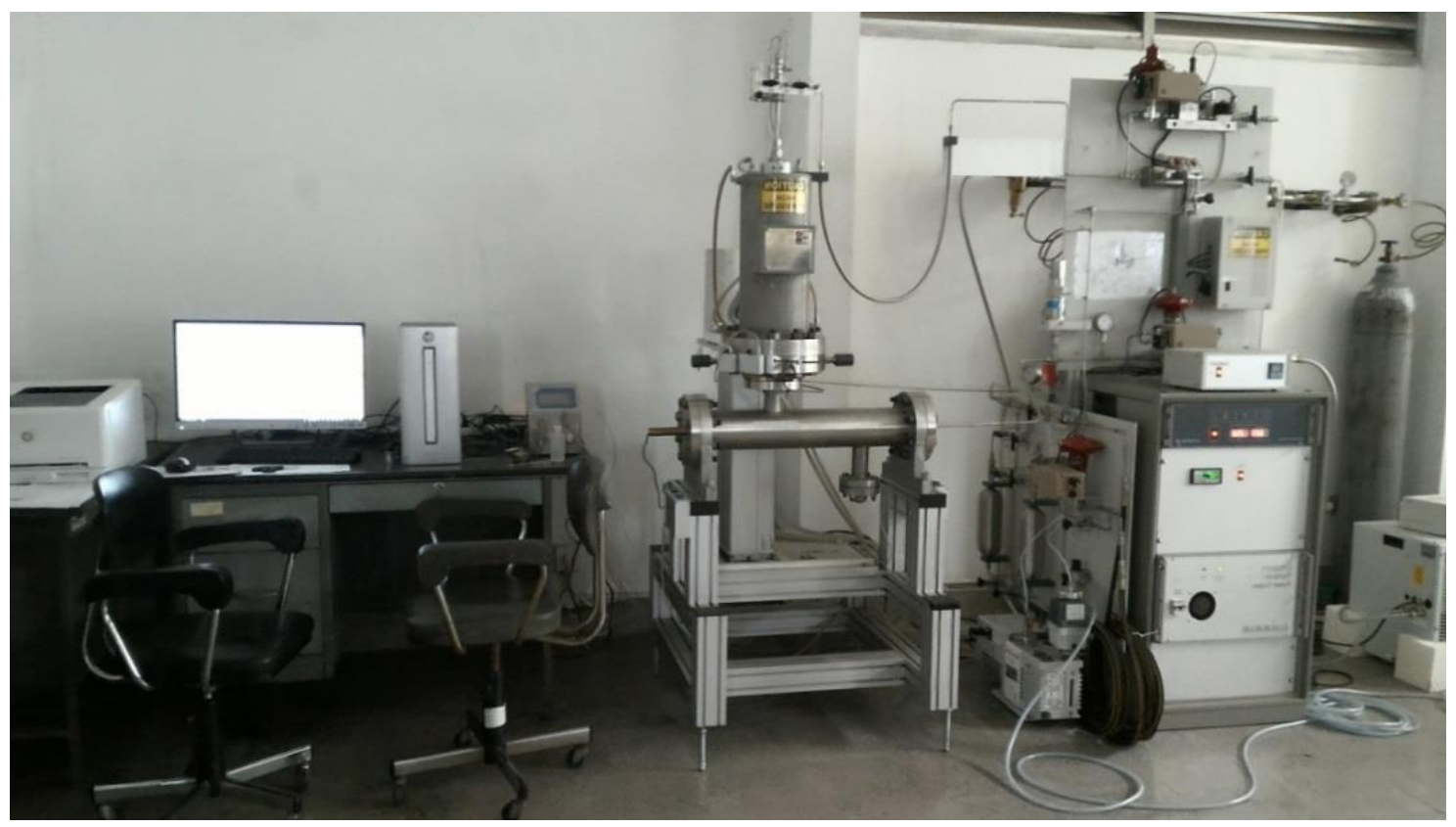

Figure 2. LINSEIS High-Pressure STA

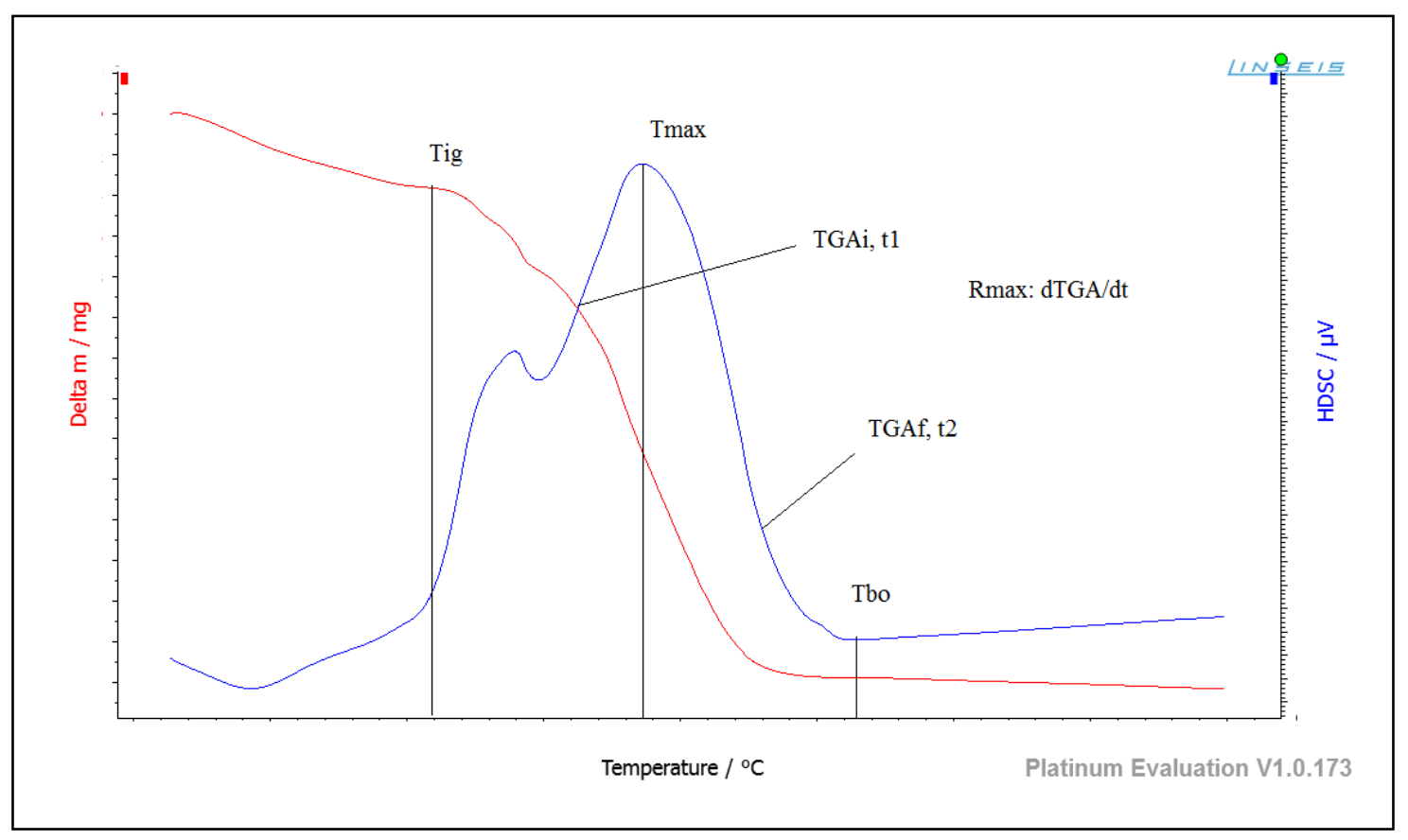

Figure 3. Combustion parameters derived from TG-DSC analysis

\section{RESULTS AND DISCUSSION}

\section{Chemical Characteristics}

The proximate analyses of inherent moisture, ash, volatile matter and fixed carbon as well as calorific value in air dried basis (ADB) of the coal and torrefied biomass including blended coal-biomass at some ratios are listed in Table 1 . The analyses were only conducted on the coal and biomasses samples, whilst the blended coal-torrefied biomass the analysis results were obtained from the calculation based on coal-torrefied biomass ratio. 
Table 1. Results of proximate analysis and calorific value (air dried basis)

\begin{tabular}{cccccccc}
\hline $\begin{array}{c}\text { Sample } \\
\text { mark }\end{array}$ & $\begin{array}{c}\text { Ratio of coal } \\
\text { and biomass } \\
\%\end{array}$ & $\begin{array}{c}\text { Inherent } \\
\text { moisture } \\
\%\end{array}$ & $\begin{array}{c}\text { Ash } \\
\%\end{array}$ & $\begin{array}{c}\text { Volatile } \\
\text { matter } \\
\%\end{array}$ & $\begin{array}{c}\text { Fixed } \\
\text { carbon } \\
\%\end{array}$ & $\begin{array}{c}\text { Calorific } \\
\text { value } \\
\text { cal/gr }\end{array}$ & $\begin{array}{c}\text { Fuel } \\
\text { ratio } \\
\text { FC/VM }\end{array}$ \\
\hline Coal & & 23.57 & 5.31 & 38.11 & 33.01 & 4461 & 0.87 \\
Twig & & 6.36 & 28.67 & 26.89 & 38.08 & 3290 & 1.42 \\
Trunk & & 6.39 & 3.58 & 26.62 & 63.41 & 6408 & 2.38 \\
Weed & & 5.93 & 59.59 & 18.73 & 15.75 & 1244 & 0.84 \\
\hline Coal- & $25: 75$ & 10.66 & 22.83 & 29.70 & 36.81 & 3583 & 1.24 \\
Twig & $50: 50: 00$ & 14.97 & 16.99 & 32.50 & 35.54 & 3876 & 1.09 \\
\hline Coal- & $75: 25: 00$ & 19.27 & 11.15 & 35.31 & 34.28 & 4168 & 0.97 \\
trunk & $55: 75$ & 10.69 & 4.01 & 29.49 & 55.81 & 5921 & 1.89 \\
\hline Coal- & $75: 25: 00$ & 14.98 & 4.45 & 32.36 & 48.21 & 5435 & 1.49 \\
weed & $50: 50: 00$ & 19.28 & 4.88 & 35.24 & 40.61 & 4948 & 1.15 \\
\hline
\end{tabular}

According to Wannapeera and Worasuwannarak (2012), the biomass generally has high moisture and volatile contents and low calorific value. As seen in Table 1, the torrefied biomasses have low moisture and volatile matter contents, lower than that of the coal. It shows that torrefaction process is effective to decrease the moisture and volatile matter contents of the biomasses. Torrefaction destructs not only the fibrous structure and tenacity of biomass but also increase the calorific value. Also after the torrefaction, the biomass has more hydrophobic characteristics that make storage of torrefied biomass more attractive to be stockpiled above non-torrefied biomass, because of the rotting behavior (Zellagui et al., 2016). During the process of torrefaction, the biomass partly devolatilizes leading to a decrease in mass, but the initial energy content of the torrefied biomass is mainly preserved in the solid product so the energy density of the biomass becomes higher than the original biomass which makes it more attractive for e.g. transportation. Another advantage of torrefied biomass is its uniformity in product quality. Woodcutting, demolition wood, waste wood after torrefaction have quite similar physical and chemical properties. (van der Stelt et al., 2011).

The coal used in this research was blended with torrefied biomasses. It has a high moisture content of $23.57 \%$. Consequently, the calorific value is low $(4,461 \mathrm{cal} / \mathrm{g})$. Therefore, the coal is categorized as low calorific value coal (Pribadi, 2016) while the calorific value of the torrefied trunk is the highest compared to that of twig and weed. It could be understood because the trunk is similar to wood that burns quite easily and produces a great deal of heat energy (Tsalidis et al., 2014). Weed has the lowest calorific value, i.e. 1,244 cal/g. The lowest basic combustion characteristics of the calorific value are predominantly caused by the higher content of inorganic substances (ash) in the leaves, i.e. $59.59 \%$. These results correspond with the results of the previous work by Pňakovič and Dzurenda (2015) who studied the combustion characteristics of the falling leaves from ornamental trees in the city and forest parks. They stated that the decline of leaves basic combustion characteristics is caused mostly by its high ash content and partially also by the higher nitrogen content - the endothermic component in the combustible matter of the leaf. The correlation between ash and calorific value of the investigated samples can be seen in Figure 4. The figure shows that the higher the ash content, the lower the calorific value. The twig and weed biomasses have low calorific value, i.e. 3,290 cal/g and $1,244 \mathrm{cal} / \mathrm{g}$ respectively. The low calorific value is mostly due to the high of ash content (28.67\% and 59.59\%). A high ash content is avoided in a coal-fired power plant because the increase of every $1 \%$ ash content will decrease the boiler efficiency approximately by $0.02 \%$ (Ma et al., 2016).

The content of fixed carbon divided by the content of volatile matter or known as fuel 
ratio is commonly used in evaluating the combustibility of coals. Generally, the fuel ratio corresponds to the heating value of the fuel. From the samples of coal, biomasses and the mixture of both that have been investigated from the trend line, it can be seen that the higher the fuel ratio the higher the calorific value of the fuel (Figure 5). The fuel ratio of the trunk is the highest, i.e. 2.38 compare to that of coal and biomasses, it indicates the ease of ignition and burnout of the trunk (Tsalidis et al., 2014). The twig biomass has a moderate fuel ratio and the weed has the lowest compared to other biomasses of trunk and twig. The low fuel ratio of the weed corresponds to its low fixed carbon and calorific value. So does the coal.
Its fuel ratio is low since the coal usually has high volatile matter content. According to Kurose et al. (2004), the lower the fuel ratio, the harder the coal to be burned. In contrast, the higher the fuel ratio, the easier the fuel to be burned. From the Table 1, the mixture of coal and biomass has the fuel ratio mostly $>1$ or nearly 1 , except for the mixtures of coal and weed fuel ratio is relatively low due to the low fuel ratio of the weed. A low fuel ratio is caused by a high volatile matter, nevertheless, the volatile matter influences the NOx formation. Generally, for the same burner and the constant nitrogen content, the higher the volatile matter the lower the NOx (Wang et al., 2017).

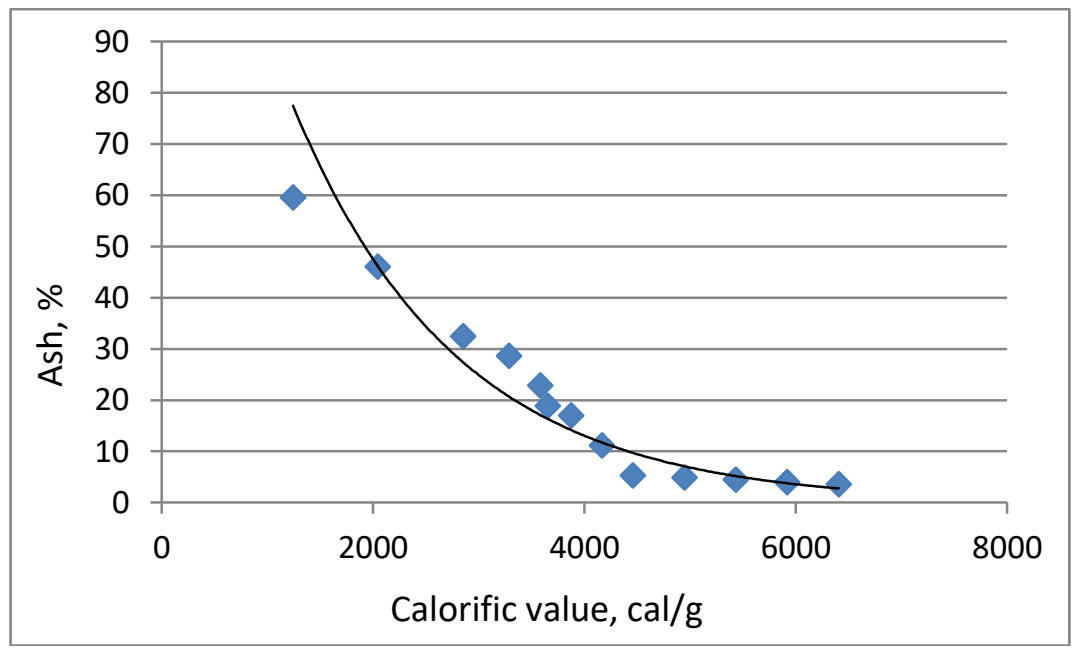

Figure 4. Calorific value vs ash of the coal, biomasses and the mixtures of both

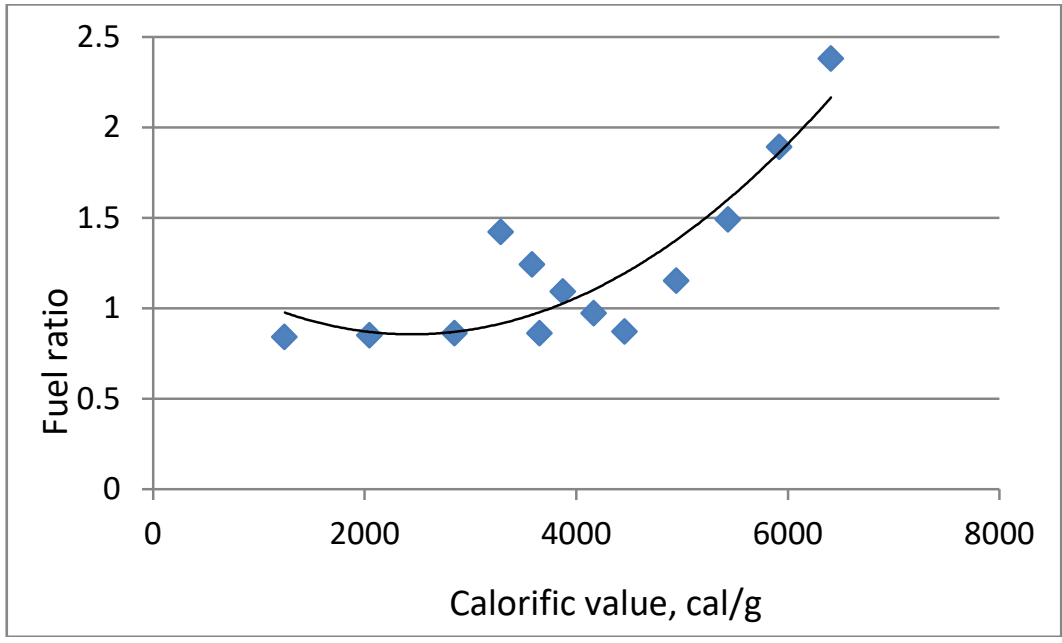

Figure 5. Calorific value vs fuel ratio of the coal, biomasses and the mixtures of both 


\section{Combustion Characteristics}

Combustion characteristics of the mixture of coal and biomasses for the co-firing system were tested by using an LINSEIS STA TGA/HDSC. From the test, the TG and HDSC curves were obtained and against the temperature. In this paper only three (3) TG/HDSC curves are shown in Figure 6 to 8 as representatives of all investigated samples, i.e. the TG-HDSC of coal, torrefied weed and a mixture of coal and torrefied weed in the ratio of 50:50.

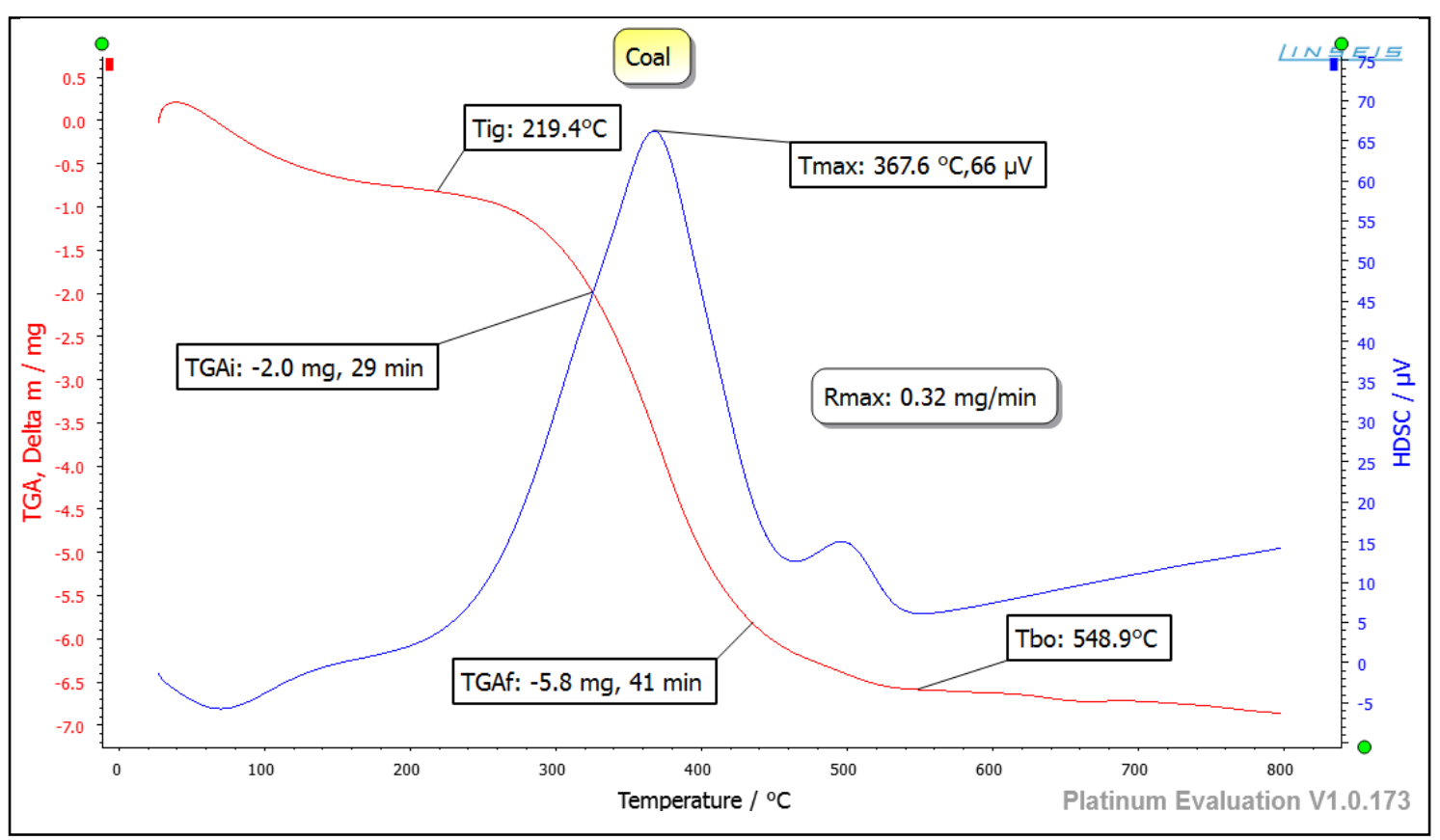

Figure 6. TG-HDSC curves of coal

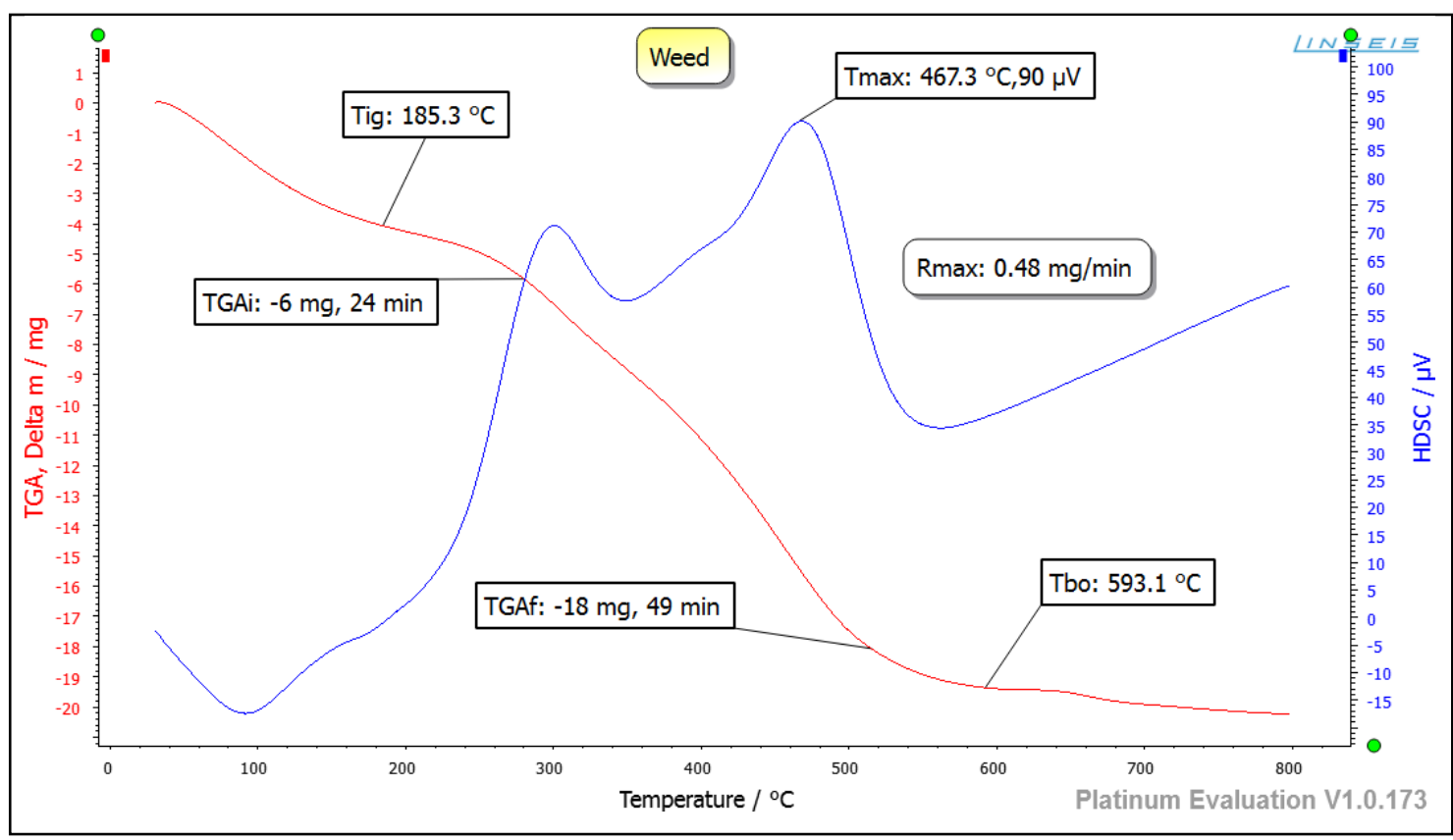

Figure 7. TG-HDSC curves of weed 


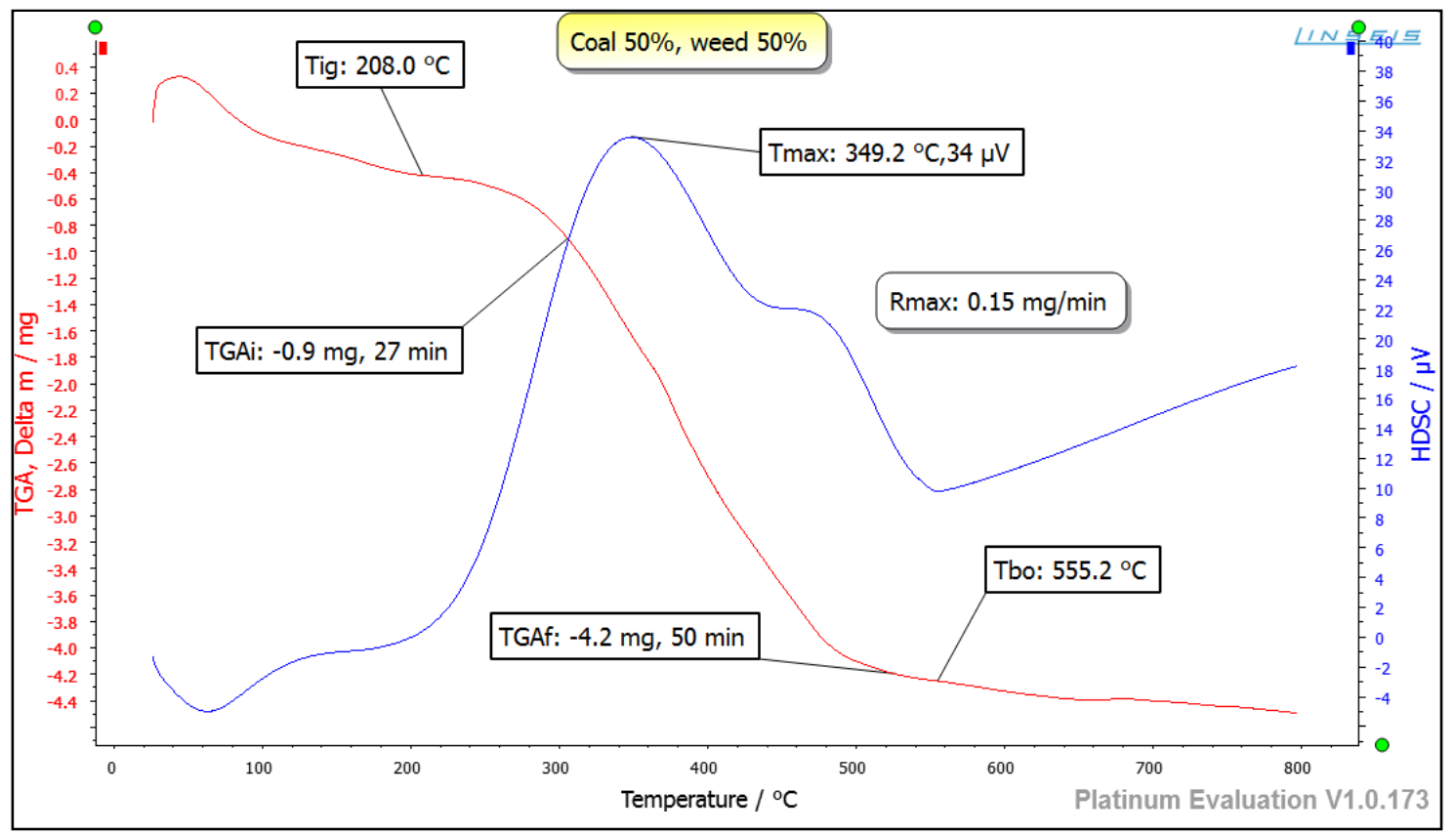

Figure 8. TG-HDSC curves of coal-weed mixture

The TG-DSC curves indicate the relative weight loss and differentiation of released heat during testing time. The TG curves for the three samples that appear in Figure 6 to 8 under oxidation in air. The initial mass loss was mainly led by water evaporation. As a result of oxygen uptake and formation of solid oxygenated complexes, the sample mass starts to increase. After reaching the maximum temperature (Tmax), the sample mass tends to decrease with the further increase in temperature. This is a sign to indicate the acceleration in the rate of thermal decomposition (endothermic) reactions. On the one hand, it makes the sample mass decreases; on the other hand, the heat absorbed by the thermal decomposition of unstable oxygenated complexes offsets in part of the heat evolved by the oxygen chemisorption, thereby reducing the rate of heat flow. The DSC curve rebounds again after slight decrease, which is assigned to the significant mass loss shown in the TG curve. This phenomenon suggests that another exothermic reaction comes into action at this stage. The variations of the TG and DSC curves for the sample heated in the aerial atmosphere are essentially related to the multiple reactions that occur during the oxidation process (Chukwu et al., 2016).
It can be seen from Figure 6 that the coal corresponds to three (3) DSC peaks due to the complicated structure of the coal which is classified as a low- rank coal. (Mahidin et al., 2003). The first DSC peak appears at around $60^{\circ} \mathrm{C}$ (endothermic) due to the vaporization of moisture, the second peak occurs at around $360^{\circ} \mathrm{C}$ (exothermic) due to the combustion of the coal and the third peak (exothermic) represents the combustion of char occurs at around $500^{\circ} \mathrm{C}$. The trend of the DSC peaks of the torrefied weed is a little bit different with the DSC peaks of the coal (Figure 7). There are also three DSC peaks, the first one or the endothermic occurs at about $80^{\circ} \mathrm{C}$ and correspond to the vaporization of the moisture.The second and the third peaks, both are exothermic, correspond to the combustion of coal. This phenomenon of two peaks might be caused by the low of fixed carbon due to the high of ash content. Those parameters may interfere the combustion process of the biomass such as weed (Idris, Rahman and Ismail, 2012). The TG-DSC curves of the coal-torrefied weed mix in the ratio of 50:50. The trend is almost the same as the TG-DSC curve of the coal (Figure 8). Several parameters derived from the TG-DSC analysis are summarized in Table 2. 
The ignition temperature (Tig) values were obtained during the TG analyses (Table 2) and the proximate analyses of the fixed carbon and the calorific value (Table 1) for the coal, the torrefied biomasses as well as the mixtures of coal and the torrefied biomasses. It can be concluded that the ignition temperature increases with the increase of fixed carbon and calorific value (Figure 9). The fixed carbon is the solid fuel that is left in the furnace after the volatile matter is distilled off. It consists mostly of carbon but also contains some hydrogen, oxygen, sulfur, and nitrogen, not driven off with the gases. The fixed carbon gives a rough estimate of calorific value. The higher the fixed carbon, the higher the calorific value and the higher the Tig.

The highest Tig was reached by the trunk at $247.7^{\circ} \mathrm{C}$. It could be understood because the trunk has high fixed carbon and heating value (63.41\% and $6,408 \mathrm{cal} / \mathrm{g}$ respectively). While the weed has the lowest Tig of $185.3^{\circ} \mathrm{C}$ due to its low fixed carbon and calorific value around $15.75 \%$ and $1,244 \mathrm{cal} / \mathrm{g}$ respectively. When the trunk was mixed with the coal in the ratio of coal to trunk of $25: 75$, the Tig provides the highest values compared to the other composition of coal and trunk, i.e. 234.0 ${ }^{\circ} \mathrm{C}$ at the calorific value of $5,921 \mathrm{cal} / \mathrm{g}$ and the mixture of coal and weed in the ratio of coal to weed of $25: 75$.

Table 2. Combustion parameters based on the TG-DSC analysis

\begin{tabular}{cccccc}
\hline $\begin{array}{c}\text { Sample } \\
\text { mark }\end{array}$ & $\begin{array}{c}\text { coal -biomass } \\
\text { ratio, \% }\end{array}$ & $\begin{array}{c}\text { Tig } \\
{ }^{\circ} \mathrm{C}\end{array}$ & $\begin{array}{c}\text { Tmax } \\
{ }^{\circ} \mathrm{C}\end{array}$ & $\begin{array}{c}\text { Rmax } \\
\mathrm{Mg} / \min \end{array}$ & $\begin{array}{c}\mathrm{Tbo} \\
{ }^{\circ} \mathrm{C}\end{array}$ \\
\hline Coal & & 219.4 & 371.9 & 0.32 & 548.9 \\
Twig & & 221.2 & 381.8 & 1.00 & 545.5 \\
Trunk & & 247.7 & 373.1 & 1.64 & 515.9 \\
Weed & & 185.3 & 472.9 & 0.48 & 593.1 \\
\hline \multirow{2}{*}{ Coal- } & $25: 75$ & 221.0 & 384.4 & 0.92 & 552.6 \\
Twig & $50: 50$ & 220.1 & 364.4 & 0.89 & 548.9 \\
& $75: 25$ & 219.9 & 299.5 & 0.88 & 558.2 \\
\hline \multirow{2}{*}{ Coal- } & $25: 75$ & 234.0 & 363.0 & 1.20 & 556.9 \\
trunk & $50: 50$ & 227.3 & 436.8 & 1.12 & 547.4 \\
& $75: 25$ & 224.6 & 296.6 & 1.10 & 535.1 \\
\hline \multirow{2}{*}{ Coal- } & $25: 75$ & 202.6 & 313.4 & 0.50 & 562.6 \\
weed & $50: 50$ & 208.0 & 356.2 & 0.25 & 555.2 \\
& $75: 25$ & 215.8 & 300.1 & 0.81 & 540.8 \\
\hline
\end{tabular}

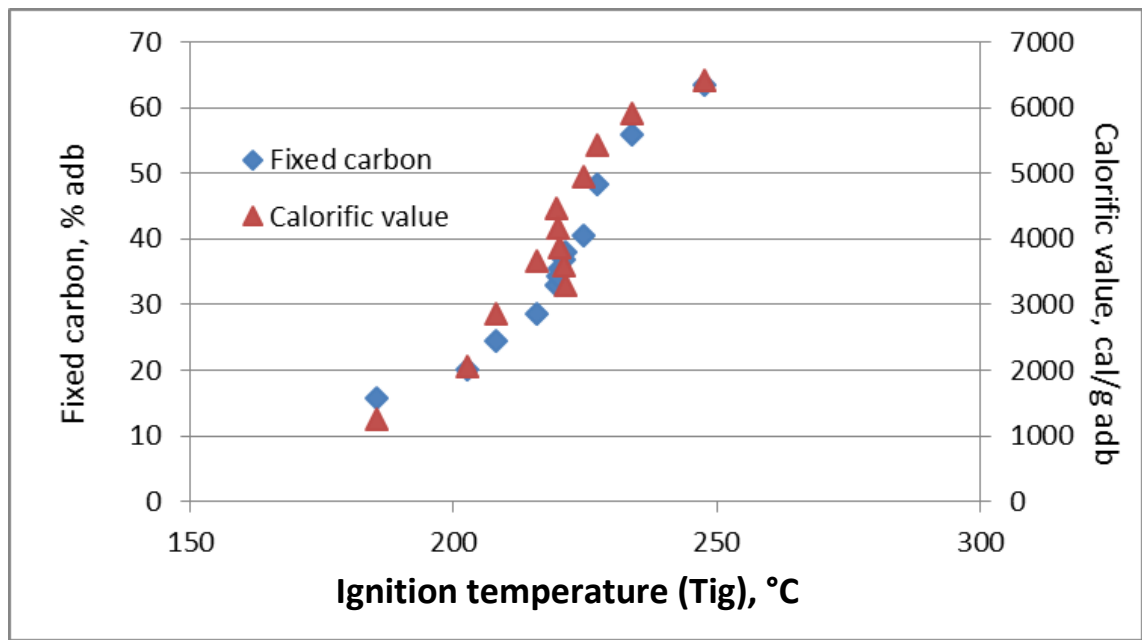

Figure 9. Tig vs the fixed carbon and the calorific value for the coal, biomasses and the mixtures of both 
Tmax relates to the reactivity. The reactive fuels have a lower Tmax. The reactivity is defined as the rate at which the fuel reacts in an oxidizing/reducing atmosphere, subsequently its de-volatilization. It describes the easiness of the fuel to reacts with the gasificant agent (e.g. oxygen). Figure 10 shows that the Tmax has no definite correlation with the Tig or the Rmax. Unlike coal, where Tmax will increase with the increasing of Tig. The results of this study show that the thermal reactivity of the biomasses changes in a wide region. Besides the effects on the burning parameters such as the ignition point, maximum rate of combustion and its temperature, on the other hand, macromolecular ingredients of biomass such as hemicelluloses, celluloses, and lignin have significant effects on the combustion behavior of biomass (Haykiri-Acma and Yaman, 2011).

The lowest Tmax is reached by coal at $371.9^{\circ} \mathrm{C}$ due to the high moisture content. The lower the Tmax, the more reactive the coal at low-temperature oxidation causes spontaneous combustion. As a result, the coal has a high tendency for spontaneous combustion. This result corresponds to the result that has been done by Beamish et al. (2012) and Wang et al. (2014) who stated that low-rank coal has a high tendency for spontaneous combustion. As mentioned above, the studied coal is classified as a low-rank coal with high moisture content and low calorific value. As the result, the heat released by the coal at the Tmax is the lowest one i.e. $69.144 \mu \mathrm{v}$.

The weed has a highest Tmax compared to the coal and the other biomasses. The high Tmax of weed $\left(472.9^{\circ} \mathrm{C}\right)$ might be caused by the very high of ash content $(59.59 \% \mathrm{adb})$. While the mixture of coal and trunk at the ratio of $50: 50$ shows the $\operatorname{Tmax}$ of $436.8^{\circ} \mathrm{C}$ with the heat release and calorific value of $164.945 \mu \mathrm{v}$ and $5,435 \mathrm{cal} / \mathrm{g}$ respectively. Heat released correspond to the activation energy for the thermal reaction. Heat released increases by the increasing of calorific value (Figure 11).

A continuous increase trend is observed for the associated amount of the heat released. These results suggest no linear dependence between the calorific value increase and the amount of the heat released. This is understandable because the biomass as a plant material due to the broadness of the term, the composition of biomass is inconsistent. The amount of heat that is produced varies depending on species, climate, and other factors.

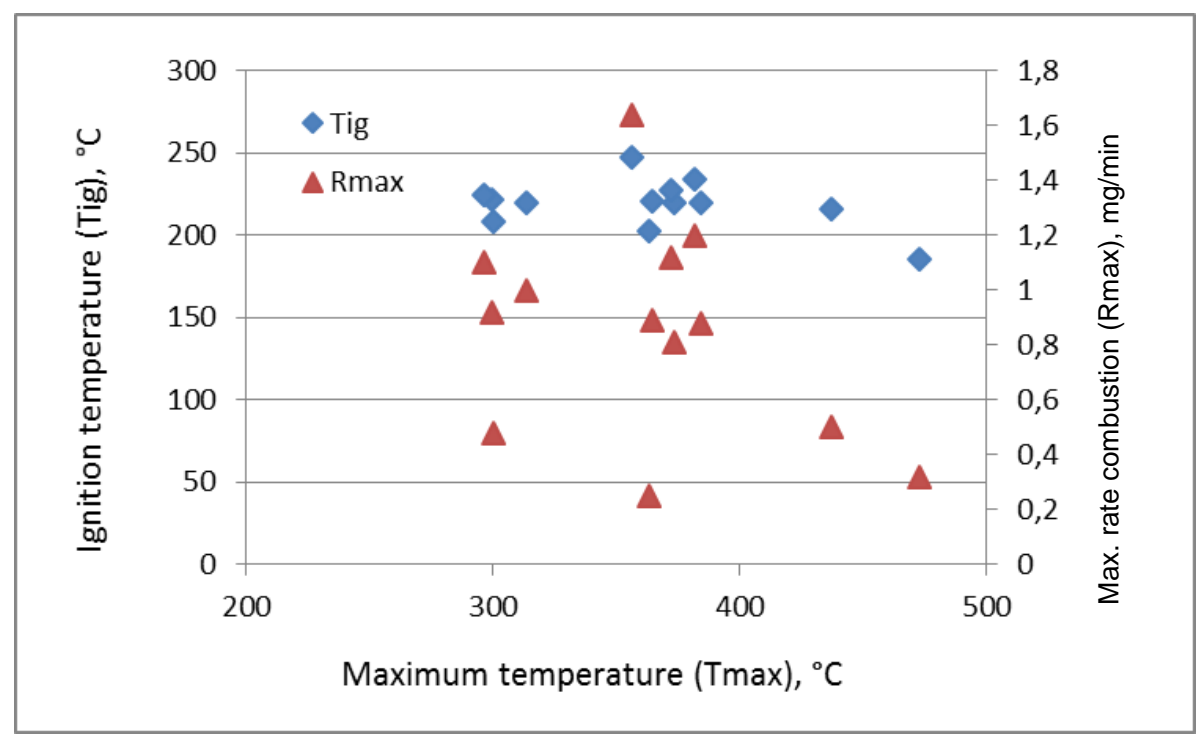

Figure 10. Tmax vs Tig and Rmax for the coal, biomasses and the mixtures of both 
Study on Combustion Characteristics of Coal-Biomass for Co-Firing System as ... Datin F. Umar et. al

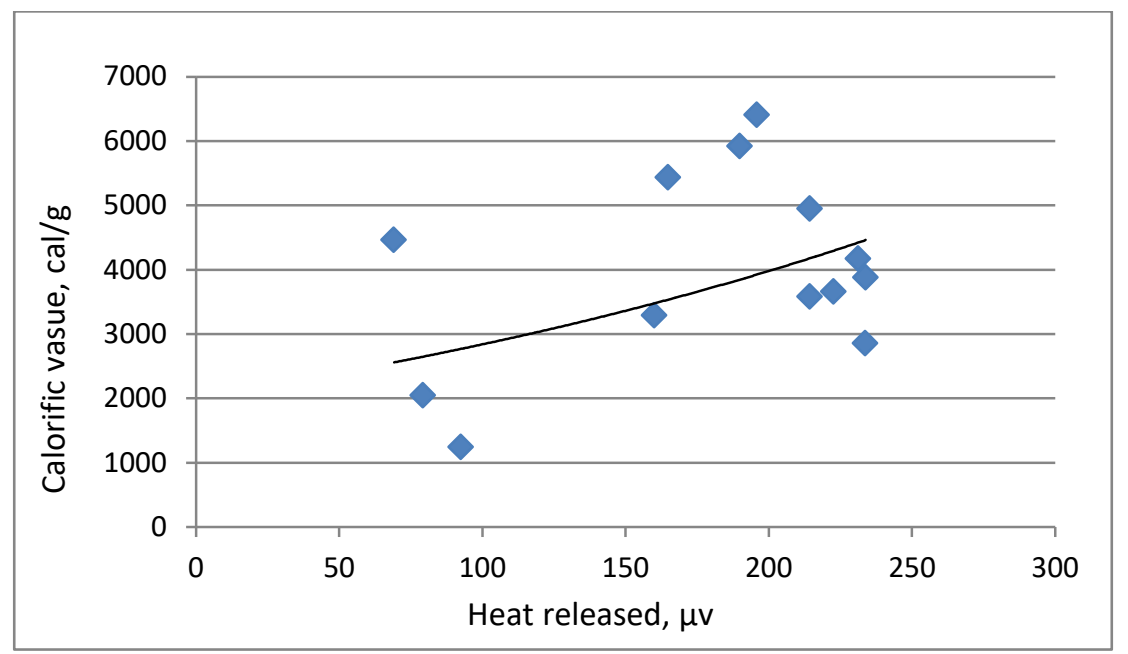

Figure 11. Heat released vs calorific value for the coal, biomasses and the mixtures of both

Different from Tmax, the Rmax indicates the maximum combustion rate has a correlation with the Tig. The higher the Rmax, the higher the Tig while the moisture content does not correspond with the moisture definitely, even though the trend shows that the moisture content decreases with the increase of Rmax (Figure 12). It shows that the fuel with high Rmax is easier to be burnt due to less the moisture content. Combustion rate is an important parameter in coal (or co-firing) fired power plant because it determines the rate at which the exhaust gases are generated from the burning propellant. This, in turn, decides the rate of fuel through the nozzle.
The mixture of coal and torrefied biomass at the ratio of $25: 75$ has the highest $R \max$ compared to another coal-biomass mixture. The high Rmax of this mixture was caused by the high Rmax of the trunk itself (1.64) and the high of Tig. The high of Rmax and the Tig mean that the fuel is ease to be burned, however, this result is not in accordance with the moisture content. All of the mixtures of coal and biomasses have high moisture content, higher than that of the single biomasses (Table 1). The high moisture content due to the high moisture content of the coal.

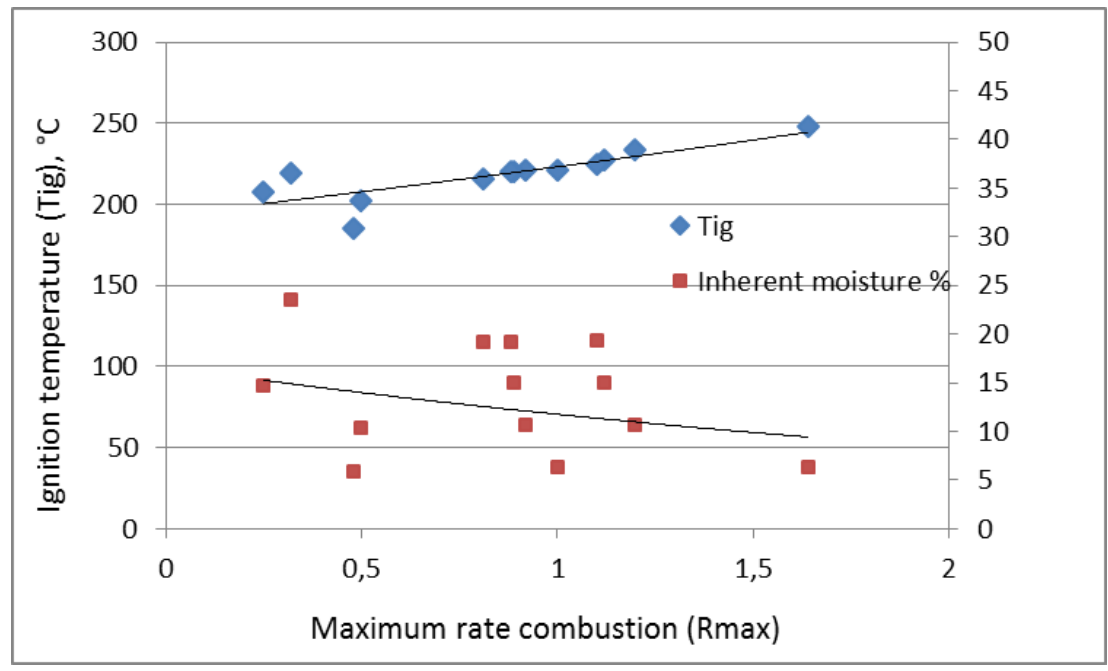

Figure 12. Rmax vs Tig and inherent moisture for the coal, biomasses and the mixtures of both 


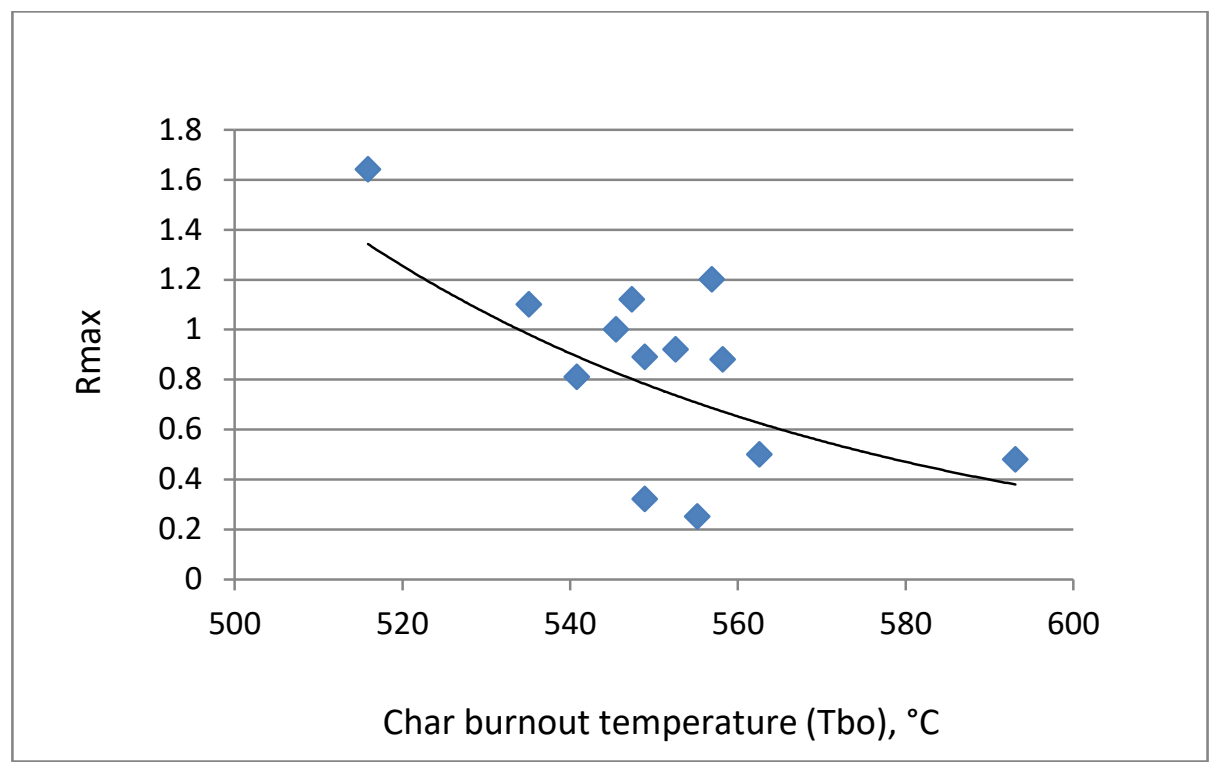

Figure 13. Tbo vs Rmax for the coal, biomasses and the mixtures of both

The Tbo reflects the char characteristics of the fuel and end of combustion (Parshetti et al., 2014). The Tbo of all samples was almost similar in the range of 515.9 and $593.1^{\circ} \mathrm{C}$ that indicates the effect of moisture and the calorific value was insignificant. The lowest Tbo is reached by torrefied trunk around $515.9^{\circ} \mathrm{C}$ and the highest by weed, namely $593.1^{\circ} \mathrm{C}$. The lowest Tbo of the torrefied trunk can be understood because the combustion rate of the trunk is also the highest one, namely $1.64 \mathrm{mg} / \mathrm{min}$. The correlation between the Rmax and the Tbo can be seen in Figure 13. The figure shows that the trend line of the Tbo decreases with the increase of the Rmax.

\section{CONCLUSION}

The experiment results indicate that the wastes from tea plantation can be used as a fuel in a co-firing system with the coal as a feedstock of gasification to convert the coal and the biomass into a combustible gas mixture referred to a producer gas $\left(\mathrm{CO}+\mathrm{H}_{2}+\mathrm{CH}_{4}\right)$ or a Syngas. The moisture content in a biomass is an important factor when it comes to combustion. The best burning fuels are dry. The mixture of coal and torrefied trunk in the weight ratio of coaltrunk of 25:75 shows the best combustion performance. The ignition temperature (Tig) of the fuel is $234.0^{\circ} \mathrm{C}$ while the maximum temperature (Tmax) is $384.4^{\circ} \mathrm{C}$ and the heat released at the Tmax is $214.411 \mu \mathrm{v}$. The maximum combustion rate ( $R$ max) is 1.20 with a moderate char burn out temperature (Tbo) of $556.9^{\circ} \mathrm{C}$. These characteristics are the best condition compared to other compositions of coal - torrefied biomass.

\section{ACKNOWLEDGEMENT}

The authors would like gratefully acknowledge the Head of R\&D Center for Mineral and Coal Technology (tekMIRA) for providing the opportunity to conduct this research. Thanks also to the staffs of tekMIRA Coal Laboratory for their assistance during the laboratory works.

\section{REFFERENCES}

Ahmed, U., Kim, C., Zahid, U., Lee, C.-J. and Han, C. (2017) "Integration of IGCC and methane reforming process for power generation with CO2 capture," Chemical Engineering and Processing: Process Intensification, 111, pp. 14-24. doi: 10.1016/j.cep.2016.10.020.

ASTM D3172-13 (2013) "Standard practice for proximate analysis of coal and coke," in. West Conshohocken: ASTM International. doi: 10.1520/D3172. 
Beamish, B., McLellan, P., Turunc, U. and Raab, M. (2012) "Quantifying spontaneous combustion inhibition of reactive coals," in 14th United States/North American Mine Ventilation Symposium. Utah: Mine Ventilation Services, pp. 1-7.

Bhattacharya, A. and Datta, A. (2015) "Effects of supplementary biomass firing on the performance of combined cycle power generation: A comparison between NGCC and IGCC plants," Biomass \& Boenergy, 54, pp. 239-249. Available at: http://aims.fao.org/serials/c_62ca0be2.

Bhuiyan, A. A. and Naser, J. (2015) "CFD modelling of co-firing of biomass with coal under oxy-fuel combustion in a large scale power plant," Fuel, 159, pp. 150-168. 10.1016/j.fuel.2015.06.058.

Cheng, Q., Wang, J., Singh, K. and Zondlo, J. (2011) "TGA-FTIR analysis of woody biomass and coal for energy production," in Proc. of FPS Conference. Oregon.

Chukwu, M., Folayan, C. O., Pam, G. Y. and Obada, D. O. (2016) "Characterization of some Nigerian coals for power generation," Journal of Combustion, 2016, pp. 1-11. doi: $10.1155 / 2016 / 9728278$.

Duong, D., Laantos, G., Tillman, D. and Kawecki, D. (2010) "Biomass Co-firing and its effect on the combustion process," in Proc. of the 35th International Technical Conference on Clean Coal \& Fuel Systems, pp. 421-429.

Haykiri-Acma, H. and Yaman, S. (2011) "Comparison of the Combustion Behaviors of Agricultural Wastes Under Dry Air and Oxygen," in World Renewable Energy Congress 2011. Linköping, pp. 251-257. doi: 10.3384/ecp11057251.

Idris, S. S., Rahman, N. A. and Ismail, K. (2012) "Combustion characteristics of Malaysian oil palm biomass, subbituminous coal and their respective blends via thermogravimetric analysis (TGA)," Bioresource Technology, 123, pp. 581-591. doi: 10.1016/j.biortech.2012.07.065.

IEA (2011) Clean energy progress report. Paris, France. Available at: https://www.iea.org/publications/freepubl ications/publication/CEM_Progress_Rep ort.pdf.
IEA (2014) World energy investment outlook. Available at: https://www.iea.org/publications/freepubl ications/publication/WEIO2014.pdf.

Kementerian Energi dan Sumber Daya Mineral (2016) "Indonesia Electricity development plan and indonesia coalash management implementation," in International Coal Based Power Conferences 2016. New Delhi.

Kurose, R., Ikeda, M., Makino, H., Kimoto, M. and Miyazaki, T. (2004) "Pulverized coal combustion characteristics of high-fuelratio coals," Fuel, 83(13), pp. 17771785. doi: 10.1016/j.fuel.2004.02.021.

Ma, Y., Yang, L., Lu, J. and Pei, Y. (2016) "Techno-economic comparison of boiler cold-end exhaust gas heat recovery processes for efficient brown-coal-fired power generation," Energy, 116, pp. 812-823.

doi: 10.1016/j.energy.2016.09.134.

Madanayake, B. N., Gan, S., Eastwick, C. and $\mathrm{Ng}, \mathrm{H}$. K. (2017) "Biomass as an energy source in coal co-firing and its feasibility enhancement via pre-treatment techniques," Fuel Processing Technology, 159, pp. 287-305. doi: 10.1016/j.fuproc.2017.01.029.

Mahidin, Ogaki, Y., Usui, H. and Okuma, O. (2003) "The advantages of vacuumtreatment in the thermal upgrading of low-rank coals on the improvement of dewatering and devolatilization," Fuel Processing Technology, 84(1-3), pp. 147-160. doi: 10.1016/S03783820(03)00052-3.

Mcllveen-Wright, D. R., Huang, Y., Rezvani, S., Mondol, J. D., Redpath, D., Anderson, M., Hewitt, N. J. and Williams, B. C. (2011) "A Techno-economic assessment of the reduction of carbon dioxide emissions through the use of biomass co-combustion is," Fuel, 90(1), pp. 1118. doi: 10.1016/j.fuel.2010.08.022.

Medic, D., Darr, M., Shah, A., Potter, B. and Zimmerman, J. (2012) "Effects of torrefaction process parameters on biomass feedstock upgrading," Fuel, 91(1), pp. 147-154. doi: 10.1016/j.fuel.2011.07.019.

Moon, C., Sung, Y., Ahn, S., Kim, T., Choi, G. and Kim, D. (2013) "Thermochemical and combustion behaviors of coals of different ranks and their blends for pulverized-coal combustion," Applied 
Thermal Engineering, 54(1), pp. 111119. doi:

10.1016/j.applthermaleng.2013.01.009.

Mun, T.-Y., Tumsa, T. Z., Lee, U. and Yang, W. (2016) "Performance evaluation of cofiring various kinds of biomass with low rank coals in a $500 \mathrm{MWe}$ coal-fired power plant," Energy, 115, pp. 954-962. doi: 10.1016/j.energy.2016.09.060.

Neupane, S., Adhikari, S., Wang, Z., Ragauskas, A. J. and Pu, Y. (2015) "Effect of torrefaction on biomass structure and hydrocarbon production from fast pyrolysis," Green Chem., 17(4), pp. 2406-2417. doi: 10.1039/C4GC02383H.

Parshetti, G. K., Quek, A., Betha, R. and Balasubramanian, R. (2014) "TGA-FTIR investigation of co-combustion characteristics of blends of hydrothermally carbonized oil palm biomass (EFB) and coal," Fuel Processing Technology, 118, pp. 228234. doi: 10.1016/j.fuproc.2013.09.010.

Pňakovič, L'. and Dzurenda, L. (2015) "Combustion characteristics of leaves fallen off ornamental trees in city and forest parks," BioResources, 10(3), pp. 5563-5572. Available at: http://ojs.cnr.ncsu.edu/index.php/BioRes /article/view/BioRes_10_3_5563_Pnako vic_Combustion_Fallen_Leaves.

Pribadi, A. (2016) "Indonesian coal policy," in Workshop On Clean Coal Technology. Cirebon, Indonesia: ASEAN Centre for Energy.

Restrepo, Á. and Bazzo, E. (2016) "Co-firing: An exergoenvironmental analysis applied to power plants modified for burning coal and rice straw," Renewable Energy, 91, pp. 107-119. doi: 10.1016/j.renene.2016.01.048.

Sarvaramini, A., Assima, G. P., Beaudoin, G. and Larachi, F. (2014) "Biomass torrefaction and $\mathrm{CO} 2$ capture using mining wastes A new approach for reducing greenhouse gas emissions of co-firing plants," Fuel, 115, pp. 749-757. doi: 10.1016/j.fuel.2013.07.087.

Septien, S., Valin, S., Dupont, C., Peyrot, M. and Salvador, S. (2012) "Effect of particle size and temperature on woody biomass fast pyrolysis at high temperature (1000-1400 C)," Fuel, 97, pp. 202-210. doi: 10.1016/j.fuel.2012.01.049. van der Stelt, M. J. C., Gerhauser, H., Kiel, J. H. A. and Ptasinski, K. J. (2011) "Biomass upgrading by torrefaction for the production of biofuels: A review," Biomass and Bioenergy. doi: 10.1016/j.biombioe.2011.06.023.

Tsalidis, G.-A., Joshi, Y., Korevaar, G. and de Jong, W. (2014) "Life cycle assessment of direct co-firing of torrefied and/or pelletised woody biomass with coal in The Netherlands," Journal of Cleaner Production, 81, pp. 168-177. doi: 10.1016/j.jclepro.2014.06.049.

Wang, J., Zheng, K., Singh, R., Lou, H., Hao, J., Wang, B. and Cheng, F. (2017) "Numerical simulation and cold experimental research of a low-NOx combustion technology for pulverized low-volatile coal," Applied Thermal Engineering, 114, pp. 498-510. doi: 10.1016/j.applthermaleng.2016.11.204.

Wang, Y., Sasaki, K., Sugai, Y. and Zhang, X. (2014) "Measurement of critical selfignition temperatures of low rank coal piles," in Proc of Coal Operators' Conference, University of Wollongong. Wolongong: The University of Wollongong, pp. 339-343. Available at: http://ro.uow.edu.au/cgi/viewcontent.cgi? article $=2190 \&$ context $=$ coal.

Wannapeera, J. and Worasuwannarak, N. (2012) "Upgrading of woody biomass by torrefaction under pressure," Journal of Analytical and Applied Pyrolysis, 96, pp. 173-180.

doi: 10.1016/j.jaap.2012.04.002.

Yan, W., Acharjee, T. C., Coronella, C. J. and Vásquez, V. R. (2009) "Thermal pretreatment of lignocellulosic biomass," Environmental Progress \& Sustainable Energy, 28(3), pp. 435-440. doi: 10.1002/ep.10385.

Zellagui, S., Schönnenbeck, C., ZouaouiMahzoul, N., Leyssens, G., Authier, O., Thunin, E., Porcheron, L. and Brilhac, J.F. (2016) "Pyrolysis of coal and woody biomass under $\mathrm{N} 2$ and $\mathrm{CO} 2$ atmospheres using a drop tube furnace experimental study and kinetic modeling," Fuel Processing Technology, 148, pp. 99-109. doi: 10.1016/j.fuproc.2016.02.007. 